\title{
Control mechanisms for the integration of teaching and service in the Pró-Saúde nursing programme
}

\author{
Mecanismos de controle da integração \\ ensino-serviço no Pró-Saúde Enfermagem \\ Mecanismos de control de la integración entre enseñanza \\ y servicio de salud em el projecto Pro-Salud Enfermería
}

\section{Selma Regina de Andrade ${ }^{a}$ \\ Astrid Eggert Boehs ${ }^{\mathrm{b}}$ \\ Carlos Gabriel Eggert Boehs ${ }^{c}$ \\ Pollyana Plautz Gorris ${ }^{d}$}

\begin{abstract}
Objective: To characterize and analyze the control mechanisms of institutional relations for the integration of health education and services linked to the Pro-Saúde programme, according to the professors and nurses of health centres in Florianópolis.

Method: A qualitative approach based on a single case study. Sixteen semi-structured interviews were conducted in the second semester of 2012 at eight health centres where nursing students carry out practical activities and internships in primary health care. The data were subjected to content analysis with the comparison of responses from both segments.

Results: Three categories were created: Characterization of control mechanisms; Influences of control mechanisms; and, Suggestions for the improvement of control mechanisms for the integration of teaching and services.

Conclusion: A greater understanding of the control mechanisms for the integration of teaching and services proportionally leads to better management of inter-organizational cooperation and the subsequent improvement of the care provided to users.
\end{abstract}

Keywords: Education, nursing. Teaching care integration services. Primary health care.

\section{RESUMO}

Objetivo: caracterizar e analisar os mecanismos de controle em relações interorganizacionais na integração entre o ensino e o serviço de saúde, vinculado ao Programa Pró-Saúde, junto aos docentes e enfermeiros assistenciais de Centros de Saúde de Florianópolis.

Método: abordagem qualitativa, estudo de caso único. Foram feitas 16 entrevistas semiestruturadas no segundo semestre de 2012, em oito Centros de Saúde, nos quais alunos de enfermagem realizam atividades práticas e estágios em atenção primária. A análise foi de conteúdo, comparando-se as respostas dos dois segmentos.

Resultados: identificadas três categorias: Caracterização dos mecanismos de controle; Influências dos mecanismos de controle; e Sugestões de aperfeiçoamento dos mecanismos de controle na integração ensino-serviço de saúde.

Conclusão: quanto maior for 0 entendimento sobre 0 controle da integração ensino e serviço, melhor será a gestão da cooperação interorganizacional e maior será a repercussão na assistência destinada ao usuário.

Palavras-chave: Educação em enfermagem. Serviços de integração docente-assistencial. Atenção primária à saude.

\section{RESUMEN}

Objetivo: caracterizar y analizar los mecanismos de control y sus influencias en la integración entre la enseñanza y el servicio de salud, vinculado al Programa Pro Salud, junto a los docentes y enfermeros asistenciales de los centros de salud de Florianópolis. Método: abordaje cualitativo, de caso único. Se realizaron 16 entrevistas semiestructuradas en el segundo semestre de 2012, en ocho Centros de Salud, en los cuales se realizan actividades prácticas y pasantías en enfermería en la atención primaria. El análisis fue de contenido, comparándose las respuestas de los dos segmentos.

Resultados: tres categorías: Caracterización de los mecanismos de control; Influencias de los mecanismos de control; y Sugerencias para la mejora de los mecanismos de control sobre la integración de la enseñanza y el servicio.

Conclusión: Cuánto mayor sea la comprensión sobre el control de esa integración, mejor será la gestión de la cooperación entre las organizaciones y la repercusión en la asistencia al usuario.

Palabras clave: Educación en enfermería. Servicios de integración enseñanza-servicio. Atención primaria de salud.
D0l: $\quad$ http://dx.doi.org/10.1590/1983-

1447.2015.03.50302 


\section{DINTRODUCTION}

The Programa Nacional de Reorientação da Formação Profissional em Saúde (National Programme for the Reorientation of Professional Health Education) - Pró-Saúde, is a governmental cooperation initiative that aims to integrate the sectors of health and teaching for the education of undergraduate students. The goal of Pró-Saúde to promote the integration of teaching and services was based on establishing a comprehensive and contextual approach to the health-sickness process, with emphasis on primary health care. Moreover, it sought to promote changes in the processes of knowledge generation by linking different approach dimensions to the needs of each social group ${ }^{(1)}$.

Consequently, the integration between municipal departments of health and the universities had to be established in order to execute the Pró-Sáude programme. In Florianopolis, Santa Catarina, the integration occurred at a strategic level - between the directors of the Universidade Federal de Santa Catarina (UFSC) and of the Secretaria Municipal de Saúde (SMSF), or the local department of health -, at a professional/academic level - between the teachers and health professionals involved in the management of resources and coordination of health centres -, and at operational level - between the nurses who provide care on a daily basis and the faculty members of the disciplines who are involved in the practice activities and internships ${ }^{(2)}$.

In order to reach the established goals within six years and ensure the continuity of the integrated activities over time, it was necessary to create joint inter-institutional mechanisms to perform the actions. These mechanisms include the control mechanisms that cover everything from the legal agreements to the tacit rules established between partners ${ }^{(3)}$. Control is one of the instruments that enables the regulation of cooperation relations and directs these relations toward the verification of performance and the monitoring of agents and factors, taking into consideration both hierarchical relationships and change processes based on socialization ${ }^{(3)}$.

The classic theoretical framework of Geringer and Hebert ${ }^{(4)}$ classifies the control mechanisms for the interaction of organizations into three categories: process-oriented, content-oriented, and context-oriented. The mechanisms of process are those by which organizations exert control through planning and decision-making processes. These processes are not only restricted to formal or informal dimensions; they also allow a range of social components. Content mechanisms specifically deal with inter-organizational relations and they are usually formal, with the direct intervention of coordinators, managers or directors. Context mechanisms are based on values, principles, and informal and cultural elements that help establish a proper setting and a common understanding, so the partners can achieve their goals with confidence and shared commitment.

Considering the importance of maintaining teaching and service integration in nursing education, within the context of primary health care, and in view of the control mechanism analysis structure in inter-organizational relations, the guiding question was: What are and how do you characterize the control mechanisms for the integration of teaching and service in the field of nursing, in the municipality of Florianópolis, for the duration of the PróSaúde programme?

Consequently, the aim of this paper is to characterize and analyze the control mechanisms in inter-organizational relations for the integration between health education and services linked to the Pró-Saúde programme, according to the faculty members and nurses of the health centres of Florianópolis.

\section{METHOD}

A qualitative study based on a single case with multiple integrated analysis units ${ }^{(5)}$. The studied case is related to the inter-organizational cooperation of the Pró-Saúde programme with the undergraduate nursing course of the UFSC and the SMSF.

For the Pró-Saúde / programme, in 2006, a close cooperation was established between the undergraduate nursing course of the UFSC and the SMSF, especially among the nursing professionals and the course professors, within the framework of Primary Health Care (PHC). The interaction included the eleven primary care units that are locally known as health centres. The chosen study sites were eight health centres that have been receiving, without interruption since 2007, nursing students doing their mandatory internship or theory and practice classes in the greatest number of subjects.

The population of the study consisted of 16 nurses, of which eight are professors and eight are attending nurses. The inclusion criteria were employed or hired professors who participate in practice activities or the internship in different subjects of the course, and attending nurses who receive students and professors for the practice activities or who supervise interns in the final semesters of the course. Nurses and professors who had been working for less than 6 months were excluded.

Data were collected from the participants at their respective workplaces by means of previously scheduled interviews that were recorded by members of the study, in the second half of 2012. The respondents were previously instructed on the meaning of control mechanisms $s^{(4)}$ and guided with open-ended questions about the types of controls, their purpose, as well as in which moments they 
were used and what influences these controls exercised on the integration between teaching and service.

The data were subjected to content analysis(6) according to the following steps: skim reading; and grouping the responses based on similarities and contrasts, which led to three categories. The data were interpreted according to the framework named mechanism control analysis structure ${ }^{(4)}$.

This study is part of the research that integrates the vector A2 - Pesquisa ajustada à realidade local, do eixo 1 - Orientação teórica, of the Programa Pró-Saúde Enfermagem - fase 3, conducted from 2011 to 2013 and the recipient of the PIBIC/CNPq grant. The authors strictly observed the recommendation of Resolution 196/96 of the Conselho Nacional de Saúde ${ }^{(7)}$, approved by the Ethics Committee of the UFSC, filed under number 2186/11, December 13, 2011, with the informed consent of all the respondents. To preserve the anonymity of the participants, the professors were identified with the letter $D$ and the attending nurses were identified with the letter $\mathrm{E}$, followed by an Arabian sequential number.

\section{RESULTS}

The analysis and interpretation of the data resulted in the following categories: Characterization of the control mechanisms used for health education and services integration; Influences of the control mechanisms for the integration of health education and services; and, Suggestions for the improvement of control mechanisms for the integration of health education and services.

\section{Characterization of control mechanisms}

The characteristics of the control mechanisms were interpreted and compared between the two institutions of teaching and services integration of the Pró-Saúde em enfermagem/UFSC. In each of the stages (between semesters; before the start of the semester; during the practice activities and internship at the health centres; at the end of the activities) they were analyzed according to type, focus/purpose and orientation (process, content and context). Based on the meaning of the control mechanism guidelines, Chart 1 compares the responses of the professors and the nurses, and the mechanisms used in the different moments of the practice and the internship in the health centres of Florianópolis.

\section{Influences of the control mechanisms for the integration of health education and services}

The professors and nurses agreed on how the adopted control mechanisms positively affect teaching and service integration. For the nurses, the control is considered cru- cial because it helps them know the work the students will complete during the semester and it allows them to evaluate this work.

The weekly meeting, which we generally schedule for the start and end of each semester, is an excellent control mechanism because it provides this space for us to listen to the opinions of the health department, of the nurses, and where we can express ourselves. D3

The partnership has to have very clear rules and the clauses have to be obeyed. The partnership is not merely built on goodwill and, in my opinion, in the case of nursing, I realize that there is a formal dynamics that manages to meet the expectations of both the University and the workers. There are conflicts, there are problems, but they are overcome, because the partnership is well structured due to formal and informal agreements (E6).

All the respondents mentioned the importance of meetings as a control mechanism in the partnership, claiming that when there is a formal process and everyone knows what the other is doing, communication problems are avoided. Control is also crucial for problem solving, since it is important for all the parties to talk after a disagreement.

If you have a time and place for discussing agreements in the practice setting, you start expanding the possibilities, you start getting to know the service better and the service starts to understand how the academics can contribute. This improves and strengthens the procedures. D6

I think these meetings are for us to know what will be done during the semester. [...] If we are aware and know what's going to happen things flow better (E5).

Contrasting the positive aspects, the nurses showed the consequences of non-use or absence of control mechanisms. Among other thoughts, they stress that when the team does not know what will happen, it cannot contribute to student education, which evidently hinders the teaching and learning process.

Yes. If there is no conversation, no organization, no schedule, then the student internships are affected. When I don't get the information, I can't plan anything (E7).

In addition to interfering with the learning process, the absence of control mechanisms also leads to unnecessary 


\begin{tabular}{|c|c|c|c|c|c|c|}
\hline \multirow[b]{2}{*}{ Stages } & \multicolumn{3}{|c|}{ Control mechanisms - UFSC } & \multicolumn{3}{|c|}{ Control mechanisms - SMSF } \\
\hline & Type & Focus/purpose & $\begin{array}{l}\text { Orientation } \\
\text { (process, } \\
\text { content and } \\
\text { context) }\end{array}$ & Tyрe & $\begin{array}{l}\text { Focus/ } \\
\text { purpose }\end{array}$ & $\begin{array}{l}\text { Orientation } \\
\text { (process, } \\
\text { content and } \\
\text { context) }\end{array}$ \\
\hline \multirow{2}{*}{$\begin{array}{l}\text { Between } \\
\text { semesters }\end{array}$} & $\begin{array}{l}\text { Meetings of the } \\
\text { management } \\
\text { committee }\end{array}$ & $\begin{array}{l}\text { Negotiating allocation } \\
\text { of students in the field }\end{array}$ & Process & $\begin{array}{l}\text { Intermediation of } \\
\text { the coordination } \\
\text { of the education } \\
\text { and service de- } \\
\text { partment }\end{array}$ & $\begin{array}{l}\text { Intervene when } \\
\text { there are prob- } \\
\text { lems in the prac- } \\
\text { tice field }\end{array}$ & Process \\
\hline & $\begin{array}{l}\text { Meeting of } \\
\text { the nurses } \\
\text { of the health } \\
\text { centres with the } \\
\text { professors }\end{array}$ & $\begin{array}{l}\text { Evaluation of the pre- } \\
\text { vious semester and } \\
\text { planning of the next } \\
\text { semester }\end{array}$ & Process & $\begin{array}{l}\text { Meeting of } \\
\text { the nurses } \\
\text { of the health } \\
\text { centres with the } \\
\text { professors }\end{array}$ & $\begin{array}{l}\text { Resume the } \\
\text { experiences of } \\
\text { the semester }\end{array}$ & Process \\
\hline \multirow[b]{3}{*}{$\begin{array}{l}\text { Before } \\
\text { Starting }\end{array}$} & \multirow{2}{*}{$\begin{array}{l}\text { Contact be- } \\
\text { tween the sub- } \\
\text { ject coordinator } \\
\text { and the coor- } \\
\text { dinator of the } \\
\text { health centre }\end{array}$} & $\begin{array}{l}\text { Reaffirm permanence } \\
\text { in the internship field. }\end{array}$ & Process & \multirow[b]{2}{*}{$\begin{array}{l}\text { Professor attend } \\
\text { planning meet- } \\
\text { ing of the health } \\
\text { centre }\end{array}$} & \multirow[b]{2}{*}{$\begin{array}{l}\text { Explanation } \\
\text { the presence of } \\
\text { students at the } \\
\text { health centre }\end{array}$} & \multirow[b]{2}{*}{ Process } \\
\hline & & $\begin{array}{l}\text { Orientation of the in- } \\
\text { ternship period, num- } \\
\text { ber of students and } \\
\text { professor responsible } \\
\text { for the activities }\end{array}$ & Content & & & \\
\hline & $\begin{array}{l}\text { Phone or e-mail } \\
\text { contact between } \\
\text { the professor and } \\
\text { the coordinator } \\
\text { of the health } \\
\text { centre. Meeting } \\
\text { at the health } \\
\text { centre }\end{array}$ & $\begin{array}{l}\text { Deliver of the schedule } \\
\text { and planning of the } \\
\text { activities of the next } \\
\text { semester }\end{array}$ & $\begin{array}{l}\text { Process/ } \\
\text { Content }\end{array}$ & $\begin{array}{l}\text { Meeting with } \\
\text { the coordinators }\end{array}$ & $\begin{array}{l}\text { Professors pres- } \\
\text { ent the schedule } \\
\text { and reserve a } \\
\text { time and day } \\
\text { in their nursing } \\
\text { consultations } \\
\text { agenda deliver } \\
\text { the curriculum }\end{array}$ & $\begin{array}{l}\text { Process/ } \\
\text { Content }\end{array}$ \\
\hline \multirow{2}{*}{$\begin{array}{l}\text { During } \\
\text { the prac- } \\
\text { tice activ- } \\
\text { ities and } \\
\text { intern- } \\
\text { ships at } \\
\text { the health } \\
\text { centre }\end{array}$} & $\begin{array}{l}\text { Informal conver- } \\
\text { sations }\end{array}$ & $\begin{array}{l}\text { On the first day, present } \\
\text { the students at the } \\
\text { health centre; Keep the } \\
\text { team informed of activ- } \\
\text { ities; Make new agree- } \\
\text { ments, negotiate activi- } \\
\text { ties; Problem solving }\end{array}$ & Process & $\begin{array}{l}\text { Informal conver- } \\
\text { sations }\end{array}$ & $\begin{array}{l}\text { Passing of infor- } \\
\text { mation when } \\
\text { new agreements } \\
\text { are made; To } \\
\text { assess the devel- } \\
\text { opment of the } \\
\text { student activities }\end{array}$ & Process \\
\hline & $\begin{array}{l}\text { Record of com- } \\
\text { pleted activities }\end{array}$ & $\begin{array}{l}\text { To avoid communica- } \\
\text { tion errors and offer } \\
\text { legal support }\end{array}$ & Content & & & \\
\hline \multirow[t]{2}{*}{$\begin{array}{l}\text { End of } \\
\text { activities }\end{array}$} & $\begin{array}{l}\text { Presentation } \\
\text { of completed } \\
\text { activities and/or } \\
\text { delivery of the } \\
\text { final report }\end{array}$ & $\begin{array}{l}\text { Reporting of the activ- } \\
\text { ities completed in the } \\
\text { semester }\end{array}$ & $\begin{array}{l}\text { Content } \\
\text { Context }\end{array}$ & $\begin{array}{l}\text { Presentation } \\
\text { of completed } \\
\text { activities and/or } \\
\text { delivery of the } \\
\text { final report }\end{array}$ & $\begin{array}{l}\text { Explain what has } \\
\text { been done in } \\
\text { the semester }\end{array}$ & $\begin{array}{l}\text { Content/ } \\
\text { Context }\end{array}$ \\
\hline & Fraternization & $\begin{array}{l}\text { Farwell event to thank } \\
\text { the team }\end{array}$ & Context & Fraternization & Thank the team & Context \\
\hline
\end{tabular}

Chart 1 - Characteristics of the control mechanisms of teaching and service integration in the different stages of the practical activities and internships. Florianópolis, Santa Catarina, Brazil 
conflicts, considering that these situations could have been resolved before the end of the activities.

They could have minimized the conflict and some situations could have been assessed and corrected even before the end of the internship (E8).

The professors also explained the consequences of the lack of control mechanisms based on the difficulties of promoting moments of integration.

[...] last semester was very hard, I think it was one of the most difficult because the meetings were very spaced out, the meetings were very scarce. Anyway, that makes it more difficult (D1).

\section{Suggestions for the improvement of control mechanisms for the integration of health education and services}

In the reports, the professors noticed the need of greater insertion in the team meetings at the health centre to strengthen the partnership.

I think the planning meeting would be one of the most important points in the process and also more, longer-lasting insertion of the professors in primary care (D8).

The nurses, in turn, also requested greater participation in the meetings of the disciplines in which students perform practice activities and complete their internships.

I think the nurse should participate in the meetings, that I think are held once a month, to learn more about the entire process, and they could extract and provide elements for the professors and get a better idea of the other side of the process (E3).

The nurses also stressed their desire to participate, along with the faculty members and the students, in assessing the progress of the practice activities and the internships during the semester:

[... I think it's always important to evaluate how the students are progressing in their activities, and this doesn't always have to be at the end, this assessment could be done during the semester so you can really change the course if it is not progressing correctly (E1).

The nurses also stressed other fundamental control mechanisms that maintain the integration of teaching and services and that include the content, process and context mechanisms:
It's always good to bring the schedule beforehand, to present the proposals, explain the objective, all that is very important [...] get to know the team. I think it is essential for the team to receive the students and the professors well. It makes a huge difference. When everything is planned in advance and notified, things flow more smoothly (E4).

The attending nurses mentioned their desire to be more active in the meeting for the nurses and professors that is held every six months.

If we had a space for meeting [...] because that one at the beginning of the semester, the meeting of the municipal nurses with the professors is beneficial, but it is usually already planned, organized by them [professors] and we don't have much room to manoeuvre. Sometimes, we get to speak when there is a gap, but I've noticed they don't want to hear a lot of things (E3).

\section{口DISCUSSION}

The characterization of the control mechanisms used to integrate teaching and services enabled the comparative analysis of the similarities and differences of the answers provided by the professors and nurses in relation to the orientation of the actions of these controls for the process, for the content and for the context ${ }^{(4)}$. In a temporal analysis, between the semesters, there was a predominance of process mechanisms, oriented by actions and practices. The controls of the cooperation process include: discussion of schedules and planning meetings, and decision making. For the start of the practice activities and internships every semester, the mechanisms of process and content ${ }^{(4)}$ were identified in the statements of the professors and teachers in relation to the negotiation between the discipline coordinator and the coordinator of the health centre.

The process mechanism(4) was characterized in the phone or e-mail contact between the professor who is directly responsible for the activities at the health centre and the coordinator of the health centre. This mechanism was also characterized in the meeting with the nurses to present the schedule, plan the student activities and assess the previous semester.

Similarly, during the practice internship activities, the process mechanism was evident in the information conversations during the semester and the renegotiations that occur on a daily basis in the practice field. This was identified in the statements of both the professors and the nurses. The aim of these informal conversations is to introduce the students, keep the team informed about the activities that are being carried out by students and professors in the 
field during the period, strengthen and make new agreements, negotiate activities, and solve problems/conflicts in the field. This leads to the assumption that the student and professor introductions to the team enable informal conversations and can therefore be classified as context mechanisms. They are considered context mechanisms because they promote knowledge between the parties, the knowledge and alignment of expectations, and the sharing of important values to promote a common culture. They also aim to establish commitment and an appropriate context of cooperation ${ }^{(4)}$. To the extent that professors, students and local team members get to know each other, they start to understand the expectations of all the parties involved, and the environment of the health centre becomes more predictable. The professors stressed the recording of the completed activities in the chart, which means a formal insertion in the health centre, with registration in the electronic system of the SMSF that guarantees the legal backing of the activities carried out by the students in the field. This record is classified as a content-oriented mechanism due to its formal and bureaucratic nature ${ }^{(4)}$.

The activities for the end of the academic semester mentioned by the professors and nurses coincided, especially the oral introduction and/or delivery of the final report in order to somehow account for the activities that were completed in the field. This activity was associated with the content-oriented mechanism due to its formal nature. At the end of the semester, they also mentioned the fraternization of the students with the staff of the health centre. This practice was identified as a context mechanism, in which relationships are cultivated and the ties between the groups and partners are strengthened. These data are compatible with the findings of another study on the cooperation between technology companies ${ }^{(8)}$, where the authors emphasize that the content-oriented, context-oriented and process-oriented control mechanisms were not only used to protect the resources between the companies; they were chiefly used to manage relations. Furthermore, there was an evident concern in guaranteeing that the trust and commitment of the counterpart were not affected.

Thus, the management of relations for the continuity of a good coexistence between the parties is fundamental to ensure that the commitment to provide health education is not restricted to student learning ${ }^{(9)}$. Health education should be committed to the resolvability of health services and, consequently, to the population ${ }^{(9)}$. This is only possible with harmonious work that is focused on common objectives.

With respect to the influences of control mechanisms on the integration of teaching and services, the results showed that professors and nurses consider these mech- anisms positive and indispensable. They stress the importance of meetings, discussing the schedule, and the students' introduction to the team, among others. Agreeing to know what each members is doing draws the groups together and builds trust, which evidently strengthens the partnership. In addition, it facilitates the work of the professors and intervenes in favour of the process of learning and insertion of the students in the health centre.

In this sense, the study highlights that "trust" and "control" should not be treated as "competitive" variables, but as interdependent dimensions in all transactions ${ }^{(10)}$. After all, it would not be possible to eliminate control entirely in favour of relations that are purely governed by trust. Another impossibility would be contexts that are purely governed by control without the elements of trust. A revision study on nursing education and health services ${ }^{(11)}$ showed that the key elements for the success of a partnership are mutual trust, a shared vision and open communication. Consequently, a horizontal relationship between professors, students and the health and nursing team of health care services should include control mechanisms that promote mutual trust and a shared vision. This would ensure that both health education and the health of the population are observed.

The more detailed suggestions mentioned by the nurses to improve the control mechanisms for the integration of teaching and health services reveal their expectations in relation to knowing and participating in education, and to having more room to manoeuvre and greater participation in the existing meetings.

In spite of the government incentives to encourage the integration of teaching and services, and in spite of the growing optimism of the professors, the results of this study are consistent with the findings in literature ${ }^{(9,11)}$. The difficulties of integrating teaching and services are related to the incipient participation of services management in the construction of curricula and the planning and development of practices. The intentions of academia and the health care network do not fully converge and the goals are not entirely common. Insofar as this reality persists, integration will continue to be a practice with many distortions ${ }^{(9)}$.

Another study(2) conducted with strategic-level members of an educational institution and a department of health showed that the respondents of the health department believe that the service is responsible for the care provided to users of the health care system. Professors and students do not follow up on their actions after the end of the semester, which reveals a gap in the partnership.

This finding refers to a study of cooperation between companies of the technology sector ${ }^{(8)}$ that showed that the greater the differences in relation to expectations and 
objectives, the greater the need to adopt formal controls such as standards and contracts.

For quality nursing care and health care to occur, the educational institutions and health services must show concern for the management of cooperation processes. These organizations are different and equally complex, but they are not opposites. Therefore, knowledge on the management of inter-organizational cooperation is essential for the integration of teaching and services ${ }^{(12)}$.

In summary, control mechanisms provide the required leverage for the management of teaching and service cooperation. Process-oriented control mechanisms ensure the dynamics and the continuity, content-oriented mechanisms establish the necessary formality, and context-oriented mechanisms foster commitment and trust in the relations between the institutions ${ }^{(4)}$.

\section{GINAL CONSIDERATIONS}

This study examined the control mechanisms for the maintenance of cooperation between professors/students and nurses of the health centres and the construction of inter-organizational management practices for educational activities. The production of systematized knowledge on teaching and service integration mechanisms revealed the main characteristics and the influences related to controlling this relationship in the context of nursing in primary care, and provided suggestions to improve these controls offered by the nurses.

As a case study, this study was limited to the reality of the city of Florianópolis and the Pró-Saúde / programme. However, the in-depth data obtained for this study serves as evidence on the importance of control mechanisms in inter-institutional relations.

It was concluded that a greater understanding of the control of teaching and service integration proportionally ensures better management of inter-organizational cooperation and a more positive impact on the care provided to users. Successful integration with shared motivations has direct implications for the permanent education and training of future nursing professional. As these professionals conduct their activities in an environment of mutual trust, they will acquire a much better understanding of the real world of work and a critical view of the advancements obtained in the care model of the Unified Health System.

\section{REFERENCES}

1. Morais FRR, Leite IDR, Oliveira LL, Veras RM. A reorientação do ensino e da prática em enfermagem: implantação do Pró-Saúde em Mossoró, Brasil. Rev Gaúcha Enferm [Internet]. 2010 [cited in 2013 oct. 20];31(3):442-9. Available at: http://dx.doi.org/10.1590/S1983-14472010000300006

2. Andrade SR, Boehs AE, Mattia D, Boehs CGE, Daussy MFS. Cooperation and the relationship between education and healthcare institutions: the nursing pró-saúde project. Texto Contexto Enferm [Internet]. 2014 [cited in 2014 feb. 20];23(1):1606. Available at: http://dx.doi.org/10.1590/50104-07072014000100019

3. Vilkamo T, Keil T. Strategic technology partnering in high-velocity environments lessons from a case study. Technovation. 2003;23(3):193-204.

4. Geringer J, Hebert L. Control and perfomance of International Joint Ventures. Journal of International Business Studies. 1989;20(2):235-54.

5. Yin RK. Estudo de caso: planejamento e métodos. 4. ed. Porto Alegre: Bookman; 2010.

6. Bardin L. Análise de conteúdo. 5. ed. rev. atual. São Paulo: Ediçōes 70; 2010.

7. Conselho Nacional de Saúde (BR). Resolução no 196/96, de 10 de outubro de 1996. Institui Diretrizes e Normas Regulamentadoras de Pesquisas envolvendo Seres Humanos [Internet]. 1996 [cited in 2014 aug. 26]. Avallable at: http:// conselho.saude.gov.br/resolucoes/1996/Reso196.doc

8. Boehs CGE, Segatto-Mendes AP. Identificação de mecanismos de controle em alianças estratégicas para desenvolvimento tecnológico: um estudo de caso no setor metal mecânico ao longo das fases de relacionamento. Rev Admin Contemp. 2007 jul./sept:;11(3):199-221.

9. Brehmer LCF, Ramos FRS. Teaching-service integration: implications and roles in experiences of Undergraduate Courses in Nursing. Rev Esc Enferm USP [Internet]. 2014 [cited in 2014 mar. 15];48(1):118-24. Available at: http://dx.doi. org/10.1590/50080-623420140000100015

10. Kirschbaum C, Hoelz JC. Mecanismos mediadores entre controle e confiança. In: VI Encontro de Estudos Organizacionais da ANPAD; 2010 jun. 23-25. Florianópolis, Brasil. Florianópolis: ANPAD; 2010. 17 f.

11. Beal JA. Academic-service partnerships in nursing: an integrative review. Nurs Res Pract [Internet]. 2012 [cited in 2013 oct. 13];28(6):327-32. Available at: http://www.ncbi.nlm.nih.gov/pmc/articles/PMC3324158/

12. Arco H, Silva C. Dilemas das redes de cooperação interorganizacionais e a formação dos profissionais de saúde: 0 caso da enfermagem [Internet]. In:VII Congresso Português de Sociologia: sociedade, crises e reconfiguraç̧ões; 2012 jun. 19-22. Porto, Portugal. Porto: Universidade do Porto; 2012 [cited in 2014 jan. 10]. 14f. Available at: http://www.aps.pt/vii_congresso/papers/finais/PAP0331_ed.pdf.

\section{Author's address:}

Selma Regina de Andrade

Campus Reitor João David Ferreira Lima

Departamento de Enfermagem, CCS

Universidade Federal de Santa Catarina, Trindade

88040-900 Florianópolis - SC

E-mail:selma.regina@ufsc.br
Received: 16.09.2014

Approved: 14.07.2015 